\title{
Histopathological Evaluation of Different Methods of Experimental Induction of Periapical Periodontitis
}

\author{
Juliane Maria Guerreiro TANOMARU ${ }^{1}$ \\ Mario Roberto LEONARDO ${ }^{1}$ \\ Léa Assed Bezerra SILVA ${ }^{2}$ \\ Ângelo POLISELI-NETO ${ }^{1}$ \\ Mário TANOMARU-FILHO ${ }^{1}$
}

${ }^{1}$ Department of Restorative Dentistry, Dental School of Araraquara, São Paulo State University, Araraquara, SP, Brazil
${ }^{2}$ Department of Pediatric Dentistry, Dental School of Ribeirão Preto, University of São Paulo, Ribeirão Preto, SP, Brazil

This study evaluated histopathologically different methods of experimental induction of periapical periodontitis. The radiographic and microbiological evaluations have been performed in a previous investigation. Fifty-seven root canals from dogs' teeth were assigned to 4 groups. In GI ( $n=14)$ and GII $(n=14)$, the root canals were exposed to oral environment for 180 days; in GIII $(n=14)$ and GIV ( $n=15)$ the root canals were exposed for 7 days and then the access cavities were restored and remained sealed for 53 days. The root apices of GI and GIII were perforated, whilst those of GII and GIV remained intact. After induction of periapical periodontitis, the dogs were euthanized. Serial sections were obtained and stained with hematoxylin and eosin. Data of the histopathological evaluation were submitted to Kruskal-Wallis and Dunn's tests at 5\% significance level. The inflammatory periapical reaction and resorption of mineralized tissues were less intense in GII than in the other groups $(p<0.05)$. There was no histopathological difference among the experimentally induced periapical lesions in the teeth with coronal sealing. On the other hand, when coronal sealing was not performed, greater intensity of induced periapical periodontitis was observed in the teeth with apical perforation.

Key Words: Endodontics, histopathological evaluation, inflammation, periapical periodontitis.

\section{INTRODUCTION}

Experimental induction of chronic periapical periodontitis in teeth of animals is important for evaluation of new root canal materials and procedures for clinical use under conditions similar to those in humans.

The biological effects of root canal filling materials and substances employed in the different phases of the root canal treatment may be investigated by 'usage tests', which is the ANSI/ADA denomination for evaluation methods that reproduce in primates and dogs the clinical conditions of use of dental materials (1). According to Spängberg (2), the histopathological evaluation of periapical tissues by different endodontic treatment protocols substantiates a scientific evidence- based clinical practice.

Therefore, models for assessment of endodontic treatment of teeth with periapical lesions should reproduce the inflammatory reaction and mineralized tissue resorption in the periapical region. Several studies have been performed in dogs to evaluate the root canal treatment of teeth with periapical lesions (3-9) or incomplete root formation (10-11) and the healing process after periapical surgery (12-13).

Periapical periodontitis can be experimentally induced by different methods. Different time periods for contamination of root canals after oral exposure can be used, as well as sealing or not of the coronal access cavity during the development of periapical periodontitis. Several authors have recommended the placement 
of coronal filling after root canal contamination to shorten the time for induction of periapical periodontitis $(3,4,6,8,11)$. Other authors advocate that the exposure of root canals to the oral environment should be maintained for longer periods (7,14-16). Another variable that can be introduced to the methods of experimental induction of periapical periodontitis is the perforation of the apical delta in the root apex of dogs' teeth. Although the dog is considered to be an excellent experimental animal model, dog's teeth end with an apical delta composed of numerous canal ramifications. This anatomic difference can be compensated by perforating the apical cementum layer with K-files in order to create a standardized apical opening (4-6, 8-11,13). Perforation of the apical delta can be accomplished shortly after exposure of the root canal or, alternately, the root apex can remain intact.

The apical and periapical healing after endodontic treatment of teeth with periradicular lesions depends directly on the induced periapical inflammatory process. Despite the large number of studies employing experimental induction of periapical periodontitis, there are no studies addressing the inflammatory reaction produced by the different methods available.

Given that the methodology of experimental induction of periapical periodontitis is a key factor for the interpretation of research results, the aim of this study was to perform a histopathological evaluation of the inflammatory reaction produced by different methods of experimental induction of periapical periodontitis in dogs' teeth.

\section{MATERIAL AND METHODS}

The second, third and fourth mandibular premolars and the second and third maxillary premolars of three dogs, totaling 57 root canals, were selected for treatment. The study design and experimental protocols were in accordance with the regulations of the local Committee of Animal Experimentation, which complies with the NIH guidelines.

The animals were anesthetized intravenously with 3\% sodium thiopental (Thionembutal, Abbot Laboratories, Rio de Janeiro, RJ, Brazil). After preparation of occlusal access cavities, the coronal pulp was removed, the root canals were explored with a size $20 \mathrm{~K}$-file (Dentsply/Maillefer, Ballaigues, Switzerland) and the radicular pulp tissue was extirpated with a size 20
Hedström file (Dentsply/Maillefer).

The root canals were assigned to 4 groups, according to the time of placement of the coronal filling and apical perforation. In GI and GII, the root canals were exposed to the oral cavity for 180 days. Onehundred and twenty days after the procedures in GI and GII, the rot canals of the other quadrants of the same dog were exposed to the oral cavity for 7 days, after which time the coronal openings were restored and remained sealed for 53 days. These root canals were included in GIII and GIV.

In GI and GIII, following pulpectomy, the root apical delta was perforated using sequential sizes 20,25 and $30 \mathrm{~K}$-files up to the total length of the root to create a standardized apical opening. A size K-file was frequently used at the root total canal length in order to confirm the standardization of the apical opening. All experimental groups were tested in the same animal and were performed in alternate quadrants.

The dogs were euthanized by anesthetic overdose 180 days after coronal opening for GI and GII and 53 days after coronal sealing for GIII and GIV. The maxillas and mandibles were removed and fixed in sodium cacodylate solution containing sucrose and glutaraldehyde. The specimens were then washed and demineralized in EDTA and glutaraldehyde activated in a microwave oven. Serial $6-\mu \mathrm{m}$-thick sections were obtained (25-30 sections per specimen) and stained with hematoxylin-eosin (HE) and Mallory Trichrome.

The pathologists who evaluated the specimens were calibrated and blinded to the groups. Histopathological examination of the apical and periapical region was carried out on the basis of the following parameters: intensity of the periapical inflammatory infiltrate, thickness of the apical periodontal ligament, bone resorption, extension of the periapical inflammatory infiltrate and apical cementum resorption. Scores of 1, 2, 3 or 4 (from best to worst) were attributed to each analyzed parameter.

The intensity of periapical inflammatory infiltrate was evaluated by counting the number of inflammatory cells in the histologic sections using a binocular light microscope (Olympus BX50, Tokyo, Japan) with a $\times 1000$ magnification ocular lens (Carl Zeiss, Optronics, $\mathrm{GmbH}$, Germany) and a $10 \times 10 \mathrm{~mm}$ test area. The median and quartiles (25\% and $75 \%$ ) were calculated from the data obtained in all groups. These values were used to establish intervals of the number of inflammatory cells corresponding to scores 1 to 4 (Table 1). 
The thickness of the apical periodontal ligament was measured in millimeters (distance between the root apex and the alveolar bone). Photomicrographs were taken at $\times 40$ magnification and digitized and the images were processed by Image Tool software for Windows version 3.0 (UTHSCSA, San Antonio, TX, USA). Statistical analysis was performed to obtain the median and quartiles (25\% and $75 \%$ ) for elaboration of scores 1 to 4 , corresponding to periodontal space thickness intervals (in $\mathrm{mm}$ ) (Table 1).

Bone resorption was analyzed based on the averages (in $\mathrm{mm}$ ) of apical periodontal ligament thickness and the following scores were attributed: 1 - absence of resorption; 2 - repaired resorption; 3 - presence of bone resorption $<1.389 \mathrm{~mm}$ (average of apical periodontal ligament thickness); and $4-\geq 1.389 \mathrm{~mm}$ (average of apical periodontal ligament thickness).

For periapical inflammatory infiltrate extension, the following scores were given: 1 - absent; 2 - restricted to the apical foramen; 3 - up to half of the apical periodontal space; 4 - beyond half of the apical periodontal space.

For apical cementum resorption, the scores were the following: 1 - absent; 2 - localized up to half of the cementum thickness; 3 - localized beyond half of the cementum thickness; 4 - reaching dentin.

The overall outcomes were calculated by adding the values of all parameters investigated for each group and then comparing the groups to each other. Statistical analysis of the histopathological parameters was performed by the Kruskal-Wallis test at 5\% significance level. When a statistically significant difference was detected, two-by-two comparisons between the experimental groups were done using Dunn's test.

\section{RESULTS}

In all 14 root canals of GI (exposure to the oral

Table 1. Distribution of specimens according to the histopathological parameters and scores.

\begin{tabular}{|c|c|c|c|c|c|}
\hline $\begin{array}{l}\text { Histological } \\
\text { parameters }\end{array}$ & Scores & $\begin{array}{c}\text { GI } \\
(n=14)\end{array}$ & $\begin{array}{c}\text { GII } \\
(\mathrm{n}=14)\end{array}$ & $\begin{array}{c}\text { GIII } \\
(\mathrm{n}=14)\end{array}$ & $\underset{(n=15)}{\text { GIV }}$ \\
\hline Inflammatory & $1=0-72.1$ inflammatory cells & 9 & 4 & - & 1 \\
\hline infiltrate & $2=72.2-87.2$ inflammatory cells & 3 & 8 & 2 & 1 \\
\hline \multirow[t]{2}{*}{ intensity } & $3=87.3-115.8$ inflammatory cells & 1 & 2 & 7 & 5 \\
\hline & $4=$ Over 115.9 inflammatory cells & 1 & - & 5 & 8 \\
\hline \multirow{4}{*}{$\begin{array}{l}\text { Apical } \\
\text { periodontal } \\
\text { space (APS) }\end{array}$} & $1=0$ to $1.068 \mathrm{~mm}$ & 2 & 9 & 2 & 1 \\
\hline & $2=1.069$ to $1.389 \mathrm{~mm}$ & 4 & 4 & 2 & 5 \\
\hline & $3=1.390$ to $1.769 \mathrm{~mm}$ & 5 & 1 & 2 & 6 \\
\hline & $4=$ Over $1.770 \mathrm{~mm}$ & 3 & - & 8 & 3 \\
\hline \multirow{4}{*}{$\begin{array}{l}\text { Bone } \\
\text { resorption }\end{array}$} & $1=$ Absent & - & - & - & - \\
\hline & $2=$ Repaired areas & - & - & - & - \\
\hline & $3=$ Non-repaired areas with APS $<1.389 \mathrm{~mm}$ & 6 & 13 & 3 & 6 \\
\hline & $4=$ Non-repaired areas with APS $\geq 1.389 \mathrm{~mm}$ & 8 & 1 & 11 & 9 \\
\hline \multirow{4}{*}{$\begin{array}{l}\text { Inflammatory } \\
\text { infiltrate } \\
\text { extension }\end{array}$} & $1=$ Absent & - & - & - & - \\
\hline & $2=$ Restricted to apical foramen & - & - & - & - \\
\hline & $3=\mathrm{Up}$ to $1 / 2$ of APS & - & 5 & - & 4 \\
\hline & $4=$ Over $1 / 2$ of APS & 14 & 9 & 14 & 11 \\
\hline \multirow{4}{*}{$\begin{array}{l}\text { Apical } \\
\text { cementum } \\
\text { resorption }\end{array}$} & $1=$ Absent & - & - & - & - \\
\hline & $2=\mathrm{Up}$ to $1 / 2$ of cementum thickness & 5 & 11 & 10 & 12 \\
\hline & $3=$ Beyond $1 / 2$ of cementum thickness & 7 & 3 & 3 & 3 \\
\hline & $4=$ Reaching dentin & 2 & - & 1 & - \\
\hline
\end{tabular}


cavity for 180 days followed by apical perforation), the inflammatory infiltrate was composed mainly by mononuclear cells (Table 1). Extensive bone resorption areas were observed (Fig. 1). The apical cementum surface exhibited partial resorption in 5 roots, total resorption in 7 roots and dentinal involvement in 2 specimens.

In GII (exposure to the oral cavity for 180 days without apical perforation), all 14 root canals exhibited

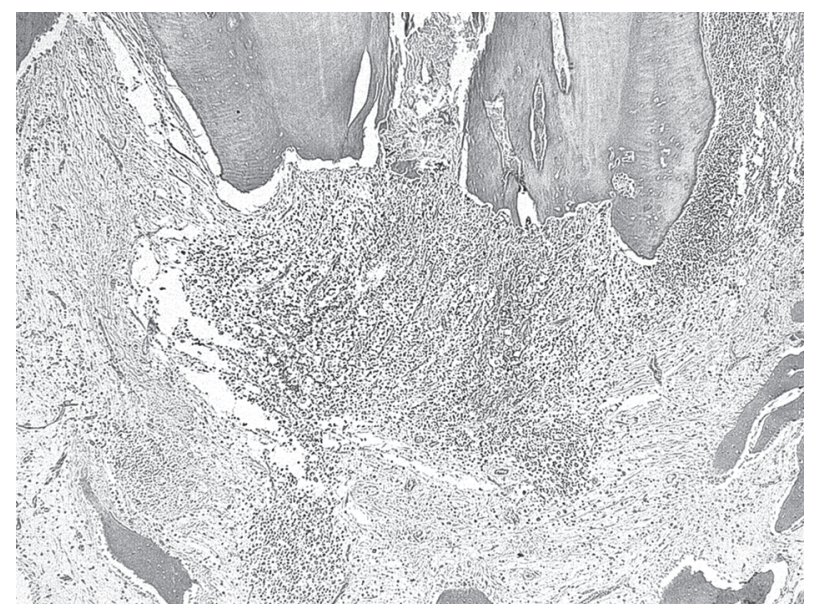

Figure 1. GI: Periapical region exhibiting intense inflammatory cell infiltrate and increase of the apical periodontal ligament thickness. HE. (Original magnification $\times 40$ ).

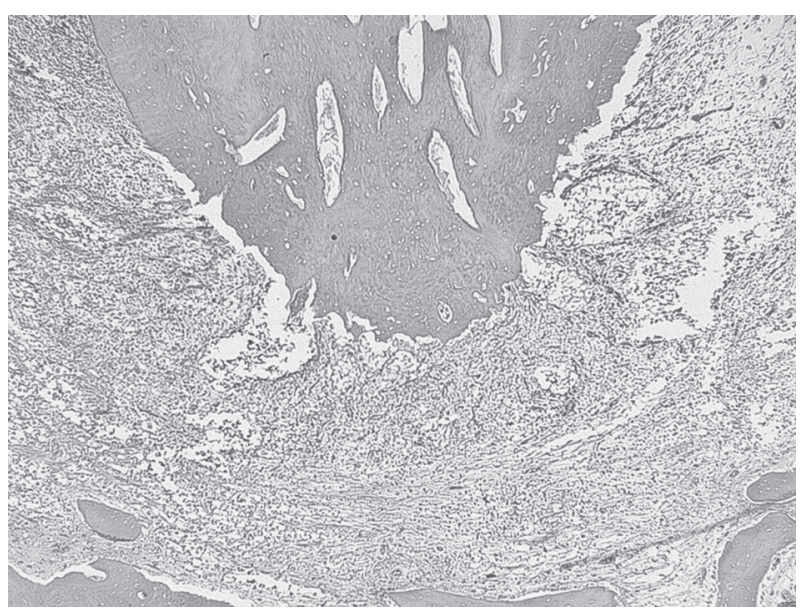

Figure 2. GII: Root apex with resorption and inflammatory cell infiltrate within the increased apical periodontal ligament. HE. (Original magnification $\times 40$ ). inflammatory alterations and mineralized tissue resorption in the apical and periapical regions, but with less intensity than in GI (Fig. 2).

The 14 root canals in GIII were exposed to the oral cavity for 7 days and remained sealed for additional 53 days with apical perforation. The intensity of inflammatory reaction in the periapical area was considered predominantly severe, being attributed scores 3 and 4 (Fig. 3). The thickness of the periodontal ligament was severely increased (score 4) in most specimens.

In GIV (coronal sealing after root canal exposure to the oral environment for 7 days without apical perforation), the periapical tissue exhibited a large number of mononuclear inflammatory cells in addition to tissue necrosis and fibril dissociation (Figs. 4 and 5). The thickness of the periodontal ligament was severely increased (score 4). Farther from the apical foramen,

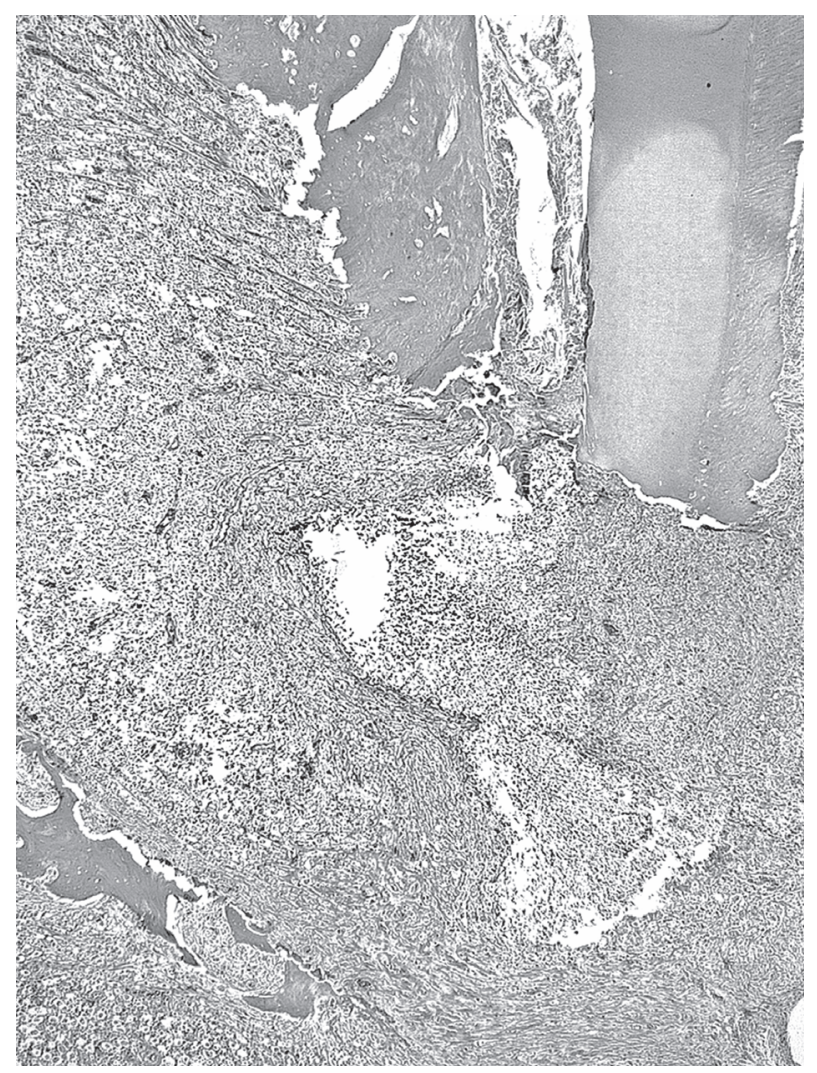

Figure 3. GIII: Periapical area with severe inflammatory cell infiltrate within the increased apical periodontal ligament. HE. (Original magnification $\times 40$ ). 
some collagen fibers were observed attempting to circumscribe the inflammatory process.

Statistical analysis of the histopathological parameters revealed significant differences among the groups ( $\mathrm{p}<0.05)$. In GII, the histopathological parameters evaluated showed a less intense inflammatory periapical reaction and resorption of mineralized tissues than in the other groups $(\mathrm{p}<0.05)$.

\section{DISCUSSION}

The methods for induction of experimental periapical periodontitis evaluated in the present study are the most frequently reported in the literature $(3,4,6-8,11,14$ $16)$, though with different periods of induction. In the methodology described by Leonardo et al. (17) for induction of periapical periodontitis in dogs' teeth, after coronal opening and removal of radicular pulp tissue, the pulp cavity was kept exposed to the oral environment for 7 days for contamination of root canals by oral microorganisms. After this period, coronal sealing was performed and maintained until radiolucent periapical areas were observed, which normally occurred within 45 to 60 days.

This methodology for inducing periapical lesions in dog's teeth has also been used in other studies $(4,5,6,8-11,18)$, which reported that after contamination of the root canals by oral pathogens or inoculation of microorganisms from the endodontic microbiota,

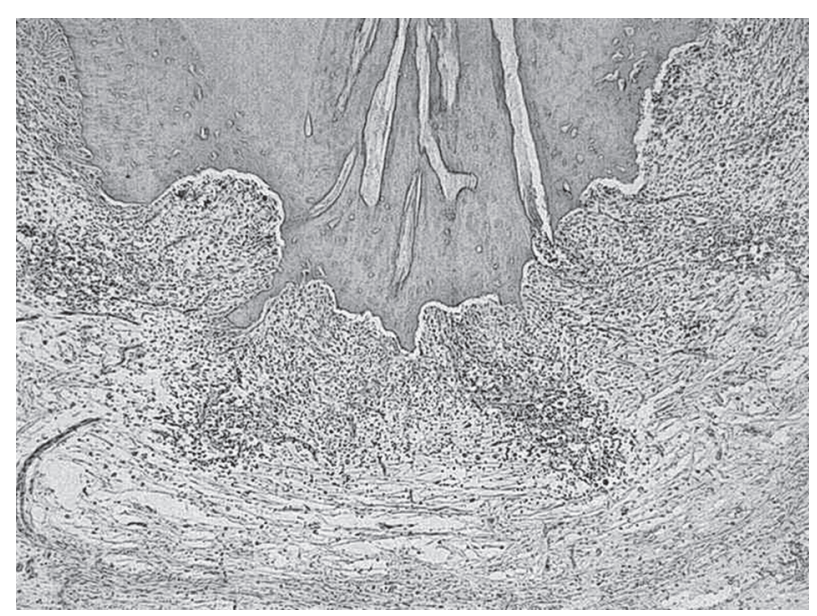

Figure 4. GIV: Apical and periapical root areas presenting extensive cementum resorption and increase of the apical periodontal ligament. HE. (Original magnification $\times 40$ ). coronal sealing reduced the time necessary for formation of radiographically visible periapical lesions. Studies have shown that when the occlusal cavities are sealed, the periapical inflammatory reaction is usually induced within 60 days $(4,6,8,11,13)$, whereas in the teeth without coronal sealing induction of periapical periodontitis occurs only after 180 days $(7,12,15)$. Similar findings were observed in the present study.

Regarding the induction of periapical inflammation, the findings of this study demonstrated that all proposed techniques induced the development of periapical lesions, which presented severe inflammatory infiltrate with predominance of mononuclear cells, thereby characterizing a chronic inflammatory reaction. For root canals exposed to the oral environment for the duration of the experiment (180 days) without apical perforation (GII), the induced periapical periodontitis exhibited less intense inflammatory parameters and less

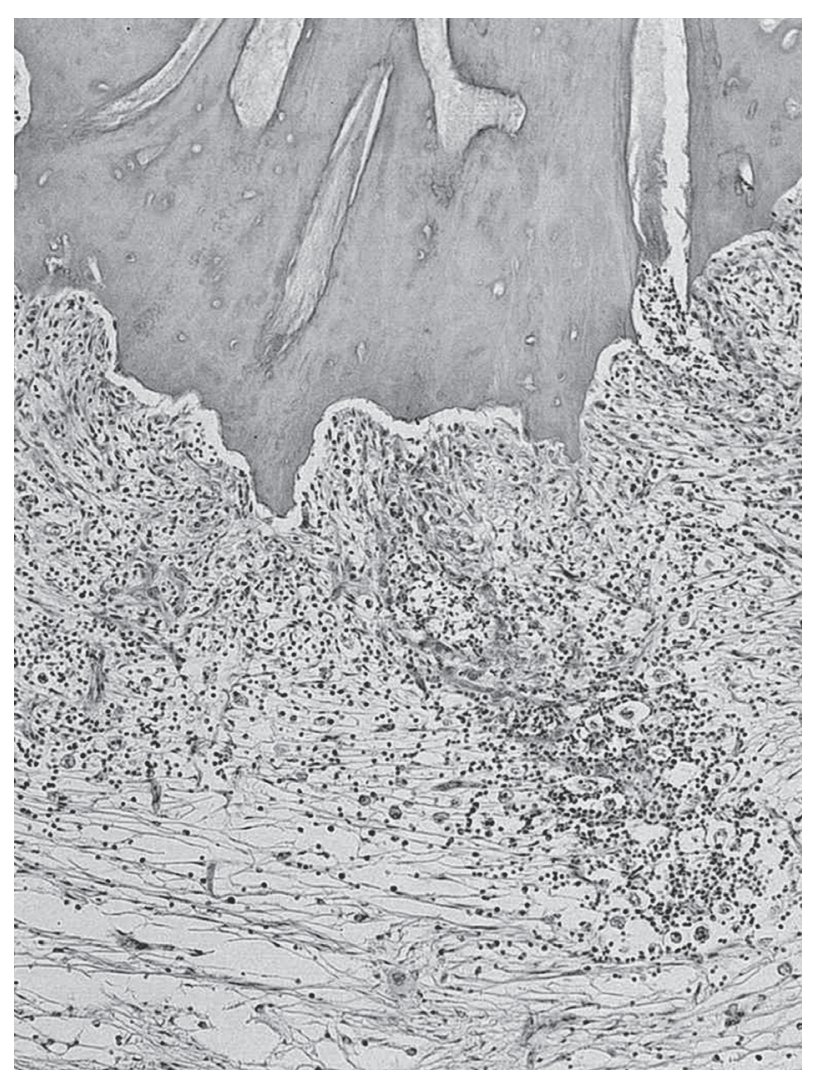

Figure 5. Greater magnification of Figure 4 showing apical cementum resorption and inflammatory cell infiltrate. HE. (Original magnification $\times 200$ ). 
apical and periapical mineralized tissue resorption compared to the other groups $(\mathrm{p}<0.05)$.

The outcomes of the present study suggest that in teeth that had the access cavities sealed, microbial shift occurred within a shorter time, resulting in a faster colonization of the root apex area by anaerobic bacteria, as observed in a previous study (19). For GIII and GIV, both with sealing of coronal openings, periapical lesions were induced in a similar manner, which suggests that apical perforation was not a significant factor.

In a previous study, Tanomaru Filho et al. (19) evaluated methods of induction of periapical periodontitis in dogs' teeth with and without coronal sealing and either perforating or not the root apices and concluded that the different methods analyzed induced the development of radiographically similar periapical lesions with predominance of anaerobic bacteria. The same specimens were used in the histopathological evaluation of the experimentally induced periapical lesions in the present study.

Ferreira et al. (20) evaluated the microbiota of root canals after inducing periapical lesions in dogs' teeth using two different methods, with and without coronal sealing, for a 120 -day period. These authors observed a larger number of strictly anaerobic microorganisms in the teeth that were sealed compared to those exposed to the oral environment. In the present study, a 60-day period was used for the sealed root canals and a 180-day period for those left exposed to the oral cavity, which has been described in previous studies $(3,7,11,14,16)$. Using the same methods for induction of apical periodontitis as those of the present study, Tanomaru-Filho et al. (19) reported the formation of periapical lesions with similar characteristics and the same type of microbiota with predominance of anaerobic microorganisms, for all induction methods. These findings were also observed in the present study.

Nevertheless, in the groups whose access cavities were not sealed, apical perforation was important for the development of periapical periodontitis, leading to induction of periapical lesions with intense inflammatory phenomena and mineralized tissue resorption, similar to the groups with coronal sealing (GIII and GIV; $\mathrm{p}>0.05)$. This may be explained by the fact that apical perforation yielded a greater access to microorganisms and their products and byproducts, thereby creating more favorable conditions for development of periapical inflammatory reaction.
The shorter period required for inducing periapical lesions when the coronal accesses of the root canals were sealed is in agreement with the findings of previous studies $(14,19)$. Jansson et al. (14), using two methods of periapical lesion induction in monkeys' teeth, with and without coronal sealing, observed that when the pulp chambers were sealed, lesion formation was faster than when they were left open, suggesting that a closed environment facilitates the development of selective anaerobic gram-negative bacteria. The pulp cavity was exposed to the oral environment for 10 to 14 days, then the crown openings were either sealed or left exposed for different experimental periods $(1,2,4,7$ and 10 months). The authors reported that the teeth with sealed root canal entrances required significantly shorter times for development of periapical lesions, which were radiographically visible after 2 months. The exhibited inflammatory infiltrate was composed mainly of mononuclear cells. However, for the teeth that did not have the access cavities sealed, periapical inflammatory reaction was observed only at 7 months.

The knowledge of the periapical periodontitis experimentally induced is important to the interpretation of research results. In this study, the obtained results showed no histopathological differences between the induced periapical lesions in the groups with coronal opening sealing and the group without coronal sealing with apical perforation. Lower intensity of induced periapical periodontitis was observed for the teeth without coronal sealing in which apical perforation was not performed. However, it is also important to consider that lesser time is required for induction of periapical periodontitis when the method with coronal sealing was used (60 days), decreasing the experimental period.

\section{RESUMO}

O objetivo deste estudo foi a avaliação de diferentes métodos de indução de lesões periapicais. Cinqüienta e seis canais radiculares de dentes de cães foram divididos em 4 grupos. No GI $(n=14)$ e no GII $(n=14)$, os canais radiculares foram expostos à cavidade bucal por 180 dias; no GIII $(n=14)$ e no GIV $(n=15)$ os canais radiculares foram expostos por 7 dias e então as aberturas coronárias foram restauradas e permaneceram seladas por 53 dias. Os ápices radiculares do GI e GIII foram perfurados, enquanto os do GII e do GIV foram mantidos intactos. Após indução das lesões periapicais, os cães foram mortos. Cortes seriados foram obtidos e corados por hematoxilina e eosina. Os dados da análise histopatológica foram submetidos ao teste de Kruskal-Wallis e Dunn com nível de significância de 5\%. A reação inflamatória periapical e reabsorção dos tecidos 
mineralizados foram menos intensos no GII que nos demais grupos $(\mathrm{p}<0,05)$. Não houve diferença histopatológica entre as lesões periapicais induzidas nos dentes com selamento coronário. Por outro lado, quando o selamento coronário não foi realizado, maior intensidade de lesão periapical induzida foi observada nos dentes com perfuração apical.

\section{REFERENCES}

1. Watts A, Paterson RC. "Usage" testing of root canal sealing materials. A critical review. J Dent 1992;20:266-271.

2. Spängberg LSW. Evidence-based endodontics: the one-visit treatment idea. Oral Surg Oral Med Oral Pathol Oral Radiol Endod 2001;91:617-618.

3. Leonardo MR, Almeida WA, Silva LAB, Utrilla LS. Histopathological observations of periapical repair in teeth with radiolucent areas submitted to two different methods of root canal treatment. J Endod 1995;21:137-141.

4. Leonardo M, Silveira FF, Silva LA, Tanomaru Filho M, Utrilla LS. Calcium hydroxide root canal dressing. Histopathological evaluation of periapical repair at different time periods. Braz Dent J 2002;13:17-22.

5. Tanomaru Filho M, Leonardo M, Silva LAB. Effect of irrigating solution and calcium hydroxide root canal dressing on the repair of apical and periapical tissues of teeth with periapical lesion. J Endod 2002;28:295-299.

6. Leonardo MR, Hernandes ME, Silva LAB, Tanomaru-Filho M. Effect of a calcium-hydroxide-based root canals dressing on periapical repair in dogs: a histological study. Oral Surg Oral Med Oral Pathol Oral Radiol Endod 2006;102:680-685.

7. Holland R, Otoboni Filho JA, de Souza V, Nery MJ, Bernabé PF, Dezan E Jr. A comparison of one versus two appointment endodontic therapy in dogs' teeth with apical periodontitis. J Endod 2003;29:121-124

8. De Rossi A, Silva LAB, Leonardo MR, Rocha LB, Rossi MA. Effect of rotary or manual instrumentation, with or without a calcium hydroxide $1 \%$ chlorhexidine intracanal dressing, on the healing of experimentally induced chronic periapical lesions. Oral Surg Oral Med Oral Pathol Oral Radiol Endod 2005;99:628-636.

9. Soares JA, Leonardo MR, Tanomaru-Filho M, Silva LAB, Ito IY. Residual antibacterial activity of chlorhexidine digluconate and camphorated p-monochlorophenol in calcium hydroxide-based root canal dressings. Braz Dent J 2007;18:8-15.
10. Leonardo MR, Silva LAB, Leonardo RT, Utrilla LS, Assed S Histological evaluation of therapy using a calcium hydroxide dressing for teeth incompletely formed apices and periapical lesions. J Endod 1993;19:348-352.

11. Shabanhang S, Torabinejad M, Boyne PP, Abedi H, McMillan P. A comparative study of root end induction using osteogenic protein-1, calcium hydroxide and mineral trioxide aggregate in dogs. J Endod 1999;25:1-5.

12. Bernabé PFE, Holland R, Morandi R, Souza V, Nery MJ, Otoboni Filho JA et al.. Comparative study of MTA and other materials in retrofilling of pulpless dog's teeth. Braz Dent J 2005;16:149-155.

13. Tanomaru-Filho M, Luis MR, Leonardo M, Tanomaru JMG, Silva LAB. Evaluation of periapical repair following retrograde filling with different root-end filling materials in dog teeth with periapical lesions. Oral Surg Oral Med Oral Pathol Oral Radiol Endod 2006;102:127-132.

14. Jansson L, Ehnevid H, Lindskog S, Blomlof L. Development of periapical lesions. Swed Den J 1993;17:85-93.

15. Estrela C, Holland R, Bernabé PEF, Souza V, Estrela CR. Antimicrobial potential of medicaments used in healing process in dog's teeth with apical periodontitis. Braz Dent J 2004; $14: 181-185$

16. de Souza RS, Gandini LG Jr, de Souza V, Holland R, Dezan E Jr. Influence of orthodontic dental movement on the healing process of teeth with periapical lesions. J Endod 2006;32:115119.

17. Leonardo MR, Almeida WA, Ito IY, Silva LAB. Radiographic and microbiologic evaluation of post-treatment apical and periapical repair of root canals of dogs teeth with experimentally induced chronic lesion. Oral Surg Oral Med Oral Patho Oral Radiol Endod 1994;78:232-238.

18. Katebzadeh N, Sigurdsson A, Trope M. Radiographic evaluation of periapical healing after obturation of infected root canals: an in vivo study. Int Endod J 2000;33:60-66.

19. Tanomaru-Filho M, Poliseli-Neto A, Leonardo M, Silva LAB, Tanomaru JMG, Ito IY. Methods of experimental induction of periapical periodontitis. Microbiological and radiographic evaluation. Int Endod J 2005;38:477-482.

20. Ferreira FF, Campos Rabang HR, Pinheiro ET, Gade-Neto CR, Zaia AA, Ferraz CC et al.. Root canal microbiota of dogs' teeth with periapical lesions induced by two different methods. Oral Surg Oral Med Oral Pathol Oral Radiol Endod 2006;102:564-567. 